\title{
Material Analysis of Projectile Hard Core
}

Ján Bezecný1 ${ }^{1}$ Ján Štrba², Andrej Dubec ${ }^{1}$

${ }^{1}$ University of Alexander Dubček in Trenčín. Faculty of Industrial Technologies. Department of Materials Engineering. I. Krasku 491/30. 02001 Púchov. Slovakia. E-mail: jan.bezecny@ fpt.tnuni.sk, andrej.dubec@ @pt.tnuni.sk

${ }^{2}$ Faculty of Special Technology, Alexander Dubček University of Trenčín, Pri parku 19, 91106 Trenčín, Slovak republic, E-mail:jan.strba@tnuni.sk

Ammunition projectiles disposal armored facilities used hard core as the main effect. The hard core has a smaller diameter than the calibre of gun. The core of the projectile is made of tungsten carbide, titanium, molybdenum or depleted uranium with a hardness of 80 to 120 measures by the Rockwell hardness test. The core must be not only hard but also tough and have a high bending strength. Knowledge of the hard core chemical composition, which the attacker uses, is important in relation to provide ballistic protection, minimization of radioactive risk and optimization of conditions for disposing of old ammunition. The basic tool for detection of the necessary data is material analysis. This analysis provides information about the weight, chemical composition and material microstructure of the hard core.

Keywords: Ammunition, Hard core, Material analysis, Chemical composition, Material microstructure

\section{References}

[1] GREXA, J., BEER, S., KOMENDA, J. (1984). Ammunition I, (in Czech), VA Brno

[2] GALETA, A., LIPTÁK, P., BUKOVINSKÝ, I. (2005). Ammunition and explosives, part I., (in Slovak), Alexander Dubček University in Trenčín, Trenčín

[3] ŠTRBA, J., PIVKO, Š. (2013). Ammunition and explosives, part III., (in Slovak), Alexander Dubček University in Trenčín, Trenčín

[4] BEER, S., KOMENDA, J., JEDLIČKA, L. (2004). Ammunition, (in Czech), UO Brno.

[5] KUSÁK, J. and collective (2008). Basic design of ammunition I., (in Czech) UP Pardubice

[6] ŠTRBA, J., GABRIŠ, M. (2013). Former Warsaw Pact Ammunition Handbook, VOL1, Land Forces Ammunition - Explosives, Projectiles and Grenades, (in English), EOD Trenčín

[7] PTÁČEK, L., et al. (2003). Material science I, (in Czech), pp. 315 - 404, academic publisher CERM, Brno, ISBN 80-7204-283-1

[8] JANDOŠ, F., ŘÍMAN, R., GEMPERLE, A., (1985). Utilization of modern laboratory methods in metallography, (in Czech), pp. 21-202, SNTL Publisher, Prague

[9] MICHALCOVÁ, A., et al. (2014). Structural description of powder metallurgy prepared materials, (in English), in: Manufacturing Technology, vol. 14, number 3, pp. 359-362, Brno

[10]KEJZLAR, P., ŠVEC, M., MACAJOVÁ, E., (2014). The usage of backscattered electrons in scanning electron microscopy, (in English), in: Manufacturing Technology, vol. 14, number 3, pp. 333-336, Brno 